\section{AMENDMENTS TO THE CONSTITUTION}

\section{ARTICLE 10 instead of}

Membership may be terminated:

a) by withdrawal, if notified at least six months in advance for the end of the year:

b) by death;

c) by expulsion, which shall be decided by the Council pursuant to Article 15 and to the ByLaws.

\section{shall read:}

Membership terminates:

a) on withdrawal, if notified at least six months in advance of the end of the year;

b) on death:

c) on failure to pay membership fees according to rule 8 of the By-Laws;

d) on expulsion, which shall be decided by the Council pursuant to Article 15 and to the By-Laws.

\section{RULE 8 instead of}

The fiscal year shall be the calendar year and membership fees shall be due on 1 January. In the event of non-payment of the fee after six calendar months membership may be terminated by the Council.

\section{shall read:}

The fiscal year shall be the calendar year and membership fees shall be due on 1 January. In the event of non-payment of the fee, membership will terminate six months after the end of the year for which payment has not been received.

\section{COMMENT:}

The previous regulations for suspension of membership were very complicated and the change is designed to provide a more severe, but nevertheless correct procedure. Due warning of suspension will, of course, be given.

\section{AMENDMENTS TO THE BY-LAWS}

\section{RULE 35}

Ordinary Members shall pay annual fees as follows:

a) Individual Ordinary Members, Constitution Article 4a)

12 units per Individual Ordinary Member

b) Societies, groups or laboratories Constitution Article $4 \mathrm{~b}$ ) according to the following scale:

first 500 members
next 500 members
next 1000 members
next 3000 members
next 5000 members
all members in excess of 10000

1 unit per member

0.7 units per member

0.6 units per member

0.5 units per member

0.4 units per member

0 units per member

c) Individual Ordinary Members, Constitution Article 4c). who are thus also members of a society, group or laboratory which is an Ordinary Member by Constitution Article 4b)

d) Individual Ordinary Members, Constitution Article 4d), who are thus also members of a Collaborating Society

Add :

4 units per Individual Ordinary Member

such number of units as decided by Council for each Collaborating Society

Notwithstanding the above, Individual Ordinary Members below 30 years of age and Individual Ordinary Members certifying their retirement from professional activities shall pay $50 \%$ of the annual fee that would otherwise be due as set out in a), c) and d) above.

\section{University College London}

Dept. of Physics and Astronomy

"New Blood" lecturer in theoretical atomic physics and astrophysics.

The above post is in the research group led by Professor M.J. Seaton. Preference will be given to applicants not older than 35 on the date (October 1985) of taking up the appointment.

Applications should be addressed to: The Assistant Secretary (Personnel)

University College London

Gower St., London WC1E 6BT

from whom further particulars may be obtained.

\section{Election of IOM Delegate to Council}

Following a very heavy poll to elect a replacement for the outgoing delegate at the completion of his term, T. Riste of Kjeller, Norway, the new IOM delegate is:

W. Thirring, Vienna, A with

M. Balkanski, Paris, F as alternate.

\section{Call for Nominations}

Proposals are now invited for the 1986 Hewlett-Packard Europhysics Prize. These may be submitted by Members individually, or as representatives of a Division and should include a:

definition of the work in question; short biography of the candidate; list of relevant publications.

Details should be sent to the Selection Committee, c/o EPS Secretariat, to arrive not later than 31 August 1985. All information will be treated as confidential. The Committee cannot enter into correspondence over the selection made.
EPS Divisions, Sections and Group

Astronomy and Astrophysics Division Solar Physics Section

Atomic and Molecular Physics Division

Atomic Spectroscopy Section

Chemical Physics

Electronic and Atomic Collisions

Molecular Physics

Computational Physics Group

Condensed Matter Division

Liquids Section

Low Temperature Physics Section

Macromolecular Physics

Magnetism

Metal Physics

Semiconductors and Insulators

Semiconductors and Ins

High Energy \& Particle Physics Division

Nuclear Physics Division

Optics Division

Plasma Physics Division

Quantum Electronics Division
Europhysics News is the official journal of the European Physical Society which comprises 29 National Societies, Academies and Group, over 3500 Individual Mem bers and 66 Associate Members. Governing bodies of EPS are the General Meeting, Council and an elected Executive Committee responsible for detailed policy. EPS promotes the collaboration of physicists throughout Europe, organising and harmonising conferences and publications, improving physics education, encouraging physics applications, awarding scholarships to sponsored schools in Erice. EPS publishes in addition to EN, Europhysics Conference Abstracts, E. Ed. News and, in collaboration with The Institute of Physics (UK) the European Journal of Physics. Individual Members receive EN free of charge (price to institutions: Sw.Fr. 90.-/a), rebates on the price of many publications and on conference fees. Annual EPS membership fee for Individual Members belonging to an EPS member society is: Sw.Fr. 40.-; independent members: Sw.Fr. 120.: members of a Collaborating Society, e.g. the American Physical Society: SwFr. 50- (\$25).

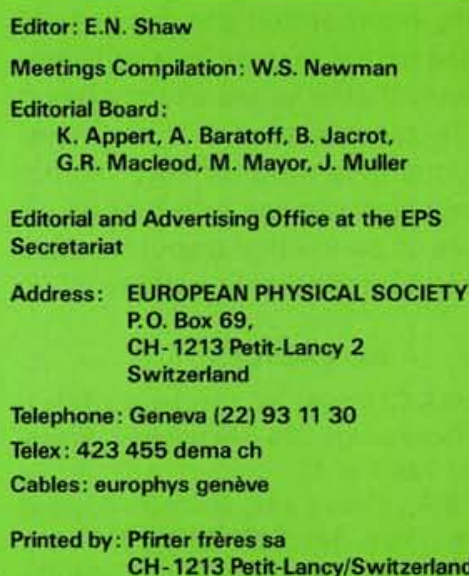

